\title{
Membaca Rasionalitas Masyarakat Islam Aboge dalam Penggunaan Sikep Penglaris di Dusun Tumpangrejo Kabupaten Malang
}

\author{
Novia Ayu Windarania ${ }^{a, 1}$, Luhung Achmad Perguna ${ }^{\mathrm{b}, 2,{ }^{*},}$, Abd. Latif Bustami $\mathrm{i}^{\mathrm{c}, 3}$ \\ abc Universitas Negeri Malang, Jalan Semarang no.5 Malang, 65144, Indonesia \\ ${ }^{1}$ noviaayuwindarani18@gmail.com; ${ }^{2}$ luhung.fis@um.ac.id; ${ }^{3}$ abd.latif.fis@um.ac.id \\ ${ }^{*}$ Corresponding Author
}

\begin{tabular}{l}
\hline INFO ARTIKEL \\
\hline Sejarah Artikel: \\
Diterima: 19 Februari 2021 \\
Direvisi: 11 Maret 2021 \\
Disetujui: 25 Maret 2021 \\
Tersedia Daring: 10 April 2021 \\
\hline
\end{tabular}

Kata Kunci:

Tradisi

Masyarakat Aboge

Sikep Penglaris

Rasionalitas

Metafisik

\begin{abstract}
ABSTRAK
Tulisan ini menggali rasionalitas penggunaan tradisi sikep penglaris masyarakat Islam Aboge di dusun Tumpangrejo kabupaten Malang dalam perspektif Webberian. Pendekatan deskriptif kualitatif digunakan dalam artikel ini dengan teknik pengumpulan data melalui observasi dan wawancara. Analisis data dengan mendeskripsikan secara mendalam data yang diperoleh melalui reduksi, interpretasi, dan penarikan kesimpulan. Penelitian menemukan bahwa rasionalitas tradisional dan rasionalitas instrumental mengemuka dalam penggunaan sikep penglaris. Salah satu rasionalitas tradisional adalah sikep penglaris merupakan tradisi turun temurun dari nenek moyang sebelum membuka usaha. Tradisi ini menjadi kesadaran kolektif masyarakat Aboge. Secara instrumental, pilihan menggunakan sikep penglaris karena munculnya ketakukan akan gangguan magis yang menyebabkan kebangkrutan atau usahanya tidak berjalan seperti yang diharapakan. Menariknya antara satu sikep penglaris dengan lainnya memiliki perbedaan. Perbedaan tersebut karena perbedaan guru spiritiual sekaligus media sikep penglaris. Bertahannya sikep penglaris tidak terlepas dari proses konstruksi yang terus berjalan secara dialektis dalam kehidupan sosial masyarakat Tumpangrejo.
\end{abstract}

Keywords:

Tradition

Aboge Society

Sikep Penglaris

Rationality

Metaphysic

\section{ABSTRACT}

This paper explores the rationality of using the tradition of sikep penglaris in the Islamic community of Aboge in Tumpangrejo, Malang Regency, from a Webberian perspective. A qualitative descriptive approach is used with data collection techniques through observation and interviews in this article. Data analysis by describing in depth the data obtained through reduction, interpretation, and drawing conclusions. Research founds that traditional rationality and instrumental rationality come to the fore in the use of sikep penglaris. One of the traditional rationalities is that sikep penglaris is a tradition passed down from generation to generation before opening a business. This tradition has become the collective consciousness of the Aboge people. Instrumentally, the choice using sikep penglaris due to the fear of magical interference that will cause bankruptcy or the business does not well as expected. Interestingly, there are differences between one sikep penglaris cycle and another. This difference is due to differences in spiritual teachers as well as sikep penglais media. The persistence of sikep penglaris cannot be separated from the construction process that continues in the social life of the Tumpanrejo community dialectically. 
(C) 2021, Windarani, Perguna, \& Bustami This is an open access article under CC-BY license

\section{Pendahuluan}

Indonesia populer dengan kemajemukan budaya yang tersebar dari Sabang sampai Merauke. Budaya ini melahirkan beragam bentuk turunan mulai dari adat istiadat, bahasa, termasuk keyakinan dan kepercayaan yang merupakan keseluruhan sistem gagasan, tindakan, dan hasil karya manusia (Koentjaraningrat, 2009). Budaya adalah sesuatu yang hidup atau nyata, berkembang, dan berwujud (Endraswara, 2006). Keberwujudannya seringkali menjadi ciri khas unik dan menjadi tradisi yang pada gilirannya akan terus diwariskan dan diinternalisasikan oleh generasi ke generasi lainnya dalam suatu masyarakat tertentu agar terus menjadi bagian integral dalam kehidupan masyarakat.

Perkembangan masyarakat yang positivistik sekaligus revolutif ditandai dengan hadirnya teknologi dan majunya ilmu pengetahuan tidak mengurangi keyakinan masyarakat yang masih memegang erat kepercayaan terhadap kekuatan gaib ataupun supernatural (Herniti, 2014). Kepercayaan sebagian masyarakat yang cenderung metafisik berpengaruh dalam perilaku kehidupan individu dan masyarakat seperti memuja, berdoa, atau perilaku lainnya yang pada gilirannya juga menimbulkan sikap mental pasrah, takut, pesimis atau malah sebaliknya seperti perasaan optimis, yakin, bahkan berani (Jaya, 2012). Beberapa warisan tradisi ini dianggap berhasil dalam menangani beragam persoalan hidup manusia di tengah masyarakat. Bertahannya tradisi di tengah deru modernitas yang terjadi saat ini menurut Simuh (2003) karena alam pikiran modern baru menyentuh lapisan minoritas kaum terpelajar saja. Tradisi tersebut juga lekat dengan ritual-ritual. Salah satu ritual dan tradisi yang masih berkembang di tengah masyarakat khususnya Jawa adalah praktik perdukunan (Nurdin, 2012; Zulfiqar, 2016).

Secara etimologi, dukun secara sederhana diartikan sebagai wong pinter (orang pintar) yang mampu menjawab ragam persoalan. Karena kemampuan itulah dukun sering dicari dan dijadikan rujukan dalam menjawab permasalahan masyarakat, mulai dari urusan asmara hingga persoalan ekonomi, pangkat, dan jabatan (Nourse, 2013). Dukun dalam praktiknya juga memberikan pelayanan masalah non-fisik, seperti gangguan makhluk halus, konsultasi mencari waktu yang tepat untuk memulai usaha, membangun rumah, menempati rumah, membangun jembatan, melaksanakan hajat, memuluskan karir, memulangkan orang yang pergi meninggalkan rumah, melancarkan sakaratul maut, serta memberikan wejangan atau nasihat mengenai permasalahan yang dihadapi masyarakat (Sartini, 2014).

Dalam kehidupan sehari-hari, manusia sebagai homo socius, yang berarti mereka butuh untuk hidup dengan makhluk lainnya, seringkali dihadapkan dengan segala bentuk permasalahan. Salah satu permasalahan khususnya bagi para pedagang adalah bagaimana memulai usaha atau berdagang sekaligus melancarkan usaha dagangnya agar terus berkembang dan tidak ketinggalan khususnya dengan pedagang Tionghoa. Pedagang Jawa cenderung enggan kerja keras yang pada praktiknya seperti hanya untuk mencari makan sehari-hari dan tidak mengarahkan usaha dagangnya ke arah yang lebih baik apabila dibandingkan dengan 
pedagang Tionghoa (Indrasuari, 2012). Bagi para pedagang, persoalan ini seringkali tidak dapat diselesaikan dengan pendekatan positivistik berbasis ilmu pengetahuan dan teknologi. Akal masyarakat berupaya untuk mencari ragam alternatif pemecahannya seperti menggunakan pendekatan metafisik atau ilmu gaib dengan bantuan dukun atau wong pinter (Arroisi, 2015; Idrus, 2007).

Dukun menjadi rujukan sekaligus alternatif dalam mengatasi ragam persoalan bagi para pedagang dalam melancarkan usahanya. Biasanya terdapat ritual yang harus dijalankan oleh pedagang untuk memuluskan usahanya, seperti meletakkan sesuatu seperti bungkusan sebagai pelarisan (jimat keberuntungan) atau melakukan ritual tertentu dengan syarat dan ketentuan yang berbeda oleh masing-masing dukun (Giri, 2010; Khoiri, 2019). Kegiatan seperti ini banyak dilakukan oleh masyarakat di Indonesia. Hal ini pula yang dilakukan oleh salah satu masyarakat di dusun Tumpangrejo, desa Kebobang, kabupaten Malang yang berprofesi sebagai pedagang.

Para pedagang khususnya warga dusun Tumpangrejo melakukan ritual yang biasa disebut sebagai sikep penglaris. Hal ini utamanya bagi masyarakat Islam Aboge di dusun ini. Meski masyarakat awam melakukan ritual, tetapi jelas terdapat perbedaan antara yang dilakukan awam dan bukan awam, yakni masyarakat Islam Aboge. Komunitas ini dikenal sangat menjunjung tinggi mitos dan tradisi kejawen dengan ragam bentuk, seperti ngitung dino (menghitung hari) sebelum melakukan hajat, nyengkalani agar mendapat perlindungan dari musibah, membuat cawisan untuk menghormati leluhur atau keluarga yang telah meninggal, termasuk menggunakan sikep penglaris khususnya bagi pedagang Islam Aboge. Ritual yang dilakukan masyarakat Aboge di dusun ini berbeda dengan yang dilakukan masyarakat Asopon (Alif Selasa Pon) di dusun yang sama.

Artikel ini fokus pada pertanyaan bagaimana proses ritual sikep penglaris di tengah masyarakat pedagang, khususnya yang dilakukan komunitas Islam Aboge di dusun Tumpangrejo dan menganalisis sejauh mana rasionalitas warga dalam melakukan ritual sikep penglaris. Dipilihnya Islam Aboge karena mayoritas warga di dusun ini merupakan penganut Aboge. Pilihan fokus pada sikep penglaris dan masyarakat Islam Aboge dilatarbelakangi beberapa sebab. Pertama, kajian sikep penglaris atau ritual tentang bagaimana usaha makin berjaya lebih banyak fokus kepada kajian teologis, metafisik yang sering nir pendekatan sosiologis (Akhmad \& Psi, 2017; Hasyim, 2018; Nourse, 2013). Kedua, kajian penglaris lebih banyak bicara pada bagaimana masyarakat awam menjadi subjek pelaku melakukan tindakan penglaris yang tidak terkait dengan Islam Aboge (Suberi, 2014). Ketiga, kajian tentang Islam Aboge banyak fokus pada persoalan toleransi, harmonisasi, kerukunan dan ajarannya (Prawiro, 2013; Sakirman, 2016; Yaqin, 2018). Dari latar tersebut, berdasarkan penelusuran peneliti belum ada penelitian yang fokus pada rasionalitas masyarakat Islam Aboge dalam penggunaan sikep penglaris sehingga kebaruan dan urgenisitas penelitian ini menjadi terang dan nampak. Pisau analisis Webber tentang tipologi tindakan sosial digunakan pada artikel ini. Harapannya penelitian ini dapat memberikan insight tentang proses penggunaan sikep penglaris sekaligus dapat mendeskripsikan rasionalitas masyarakat Islam Aboge dan konstruksinya di masyarakat yang eksis hingga sekarang.

Untuk menganalisis data-data yang telah diperoleh dalam penelitian ini menggunakan dua teori yaitu pertama teori tindakan sosial Webber untuk menganalisis latar belakang yang mendasari penggunaan sikep penglaris oleh masyarakat Dusun Tumpangrejo. Dalam teori Tindakan Sosial Webber menekankan pada tiga aspek yang menjadi fokus utama pada teori ini yaitu perhatian pada individu, pola dan regularitas tindakan (Ritzer \& Goodman, 2016). Dalam melakukan sebuah tindakan, setiap individu berpotensi memiliki pemahaman yang bersebrangan, maka dari itu melalui teori ini kita dapat melihat secara jelas perbedaan 
tersebut melalui tindakan yang dilakukan oleh masing-masing individu. Weber juga mengungkapkan bahwa dengan menghargai ragam tindakan yang oleh suatu kelompok yang dijadikan sebagai sebuah ciri khas merupakan solusi terbaik untuk memahami berbagai kelompok. Dari situ nantinya kita akan dapat melihat dengan jelas apa latar belakang yang mendasari individu atau warga masyarakat melakukan tindakan tersebut (Jones, 2003).

Dalam mengkaji suatu tindakan, teori tindakan sosial Weber digolongkan menjadi empat tipe tindakan dasar yaitu pertama Rasional Instrumental adalah tindakan yang ditujukan pada pencapaian tujuan-tujuan secara rasional diperhitungkan dan diupayakan sendiri oleh individu yang bersangkutan. Kedua, Rasionalitas Nilai adalah tindakan yang dilakukan untuk alasan-alasan dan tujuan-tujuan yang ada kaitannya dengan nilai-nilai yang diyakini secara personal tanpa memperhitungkan prospek-prospek yang ada kaitannya dengan berjasil atau gagalnya tindakan tersebut. Ketiga, Tindakan Afektif adalah tindakan yang ditentukan oleh kondisi-kondisi dan orientasi-orientasi emosional individu. Keempat, Tindakan Tradisional adalah tindakan yang ditentika oleh kebiasaankebiasaan yang sudah mengakar secara turun-temurun (Turner, 2012).

\section{Metode}

Artikel hasil penelitian ini menggunakan pendekatan penelitian deskriptif kualitatif (Neuman 2014) dengan menyajikan dan mendeskripsikan rasionalitas warga terhadap penggunaan sikep penglaris pada masyarakat dusun Tumpangrejo, desa Kebobang, kabupaten Malang. Sumber data dalam penelitian ini adalah pembuat sikep penglaris, pengguna sikep penglaris, tokoh masyarakat, termasuk pula perangkat desa dengan jumlah 9 orang informan. Informan dipilih dengan metode purposive yang dianggap merepresentasikan identitasnya baik sebagai pembuat, pengguna, hingga tokoh masyarakat sehingga data yang didapatkan sesuai dengan tujuan penelitian. Pengambilan data dilakukan melalui tahap observasi non partisipan. Peneliti hadir langsung di lokasi dan membaur bersama masyarakat sebagai upaya mendapatkan pengalaman langsung tentang penggunaan sikep penglaris. Observasi ini untuk mengamati berbagai aktivitas partisipan sekaligus mendalami proses yang berlangsung dalam tradisi sikep penglaris yang berkaitan dengan rasionalitas pengguna sikep penglaris beserta unsurunsur simbolik yang digunakan.

Tahap selanjutnya yaitu dengan wawancara kepada para informan yang merujuk kepada fokus penelitian tentang rasionalitas penggunaan sikep penglaris, yaitu Mbah Cipto sebagai tokoh masyarakat Islam Aboge di dusun, Mbah Sutik pembuat sikep penglaris, Kuswari perangkat desa, serta Ida, Menik, dan Narni sebagai pengguna. Wawancara dilakukan dengan menggunakan bahasa Jawa krama agar dapat menggali informasi secara mendalam dan informan tidak canggung untuk menjawab pertanyaan yang diajukan dikarenakan keseharian mereka menggunakan bahasa Jawa. Jenis wawancara dilakukan secara tidak terstruktur dalam arti bahwa pertanyaan dan jawaban mengalir secara natural tanpa terikat dengan tujuan. Hal ini dilakukan agar informan dan peneliti dapat merasakan kenyamanan dan kebebasan dalam berkomunikasi dengan harapan hasil yang diperoleh menyeluruh tanpa meninggalkan fokus utama penelitian. Wawancara dilakukan pada Mei-Oktober 2020 secara tidak terstruktur. Untuk mengantisipasi kehilangan data dan lupa dengan informasi yang telah didapat karena banyaknya informasi, peneliti membuat catatan dan merekam hasil wawancara tanpa terlihat oleh informan agar informan merasa nyaman.

Tahap terakhir pengambilan data yaitu melalui dokumentasi. Dokumentasi adalah setiap bahan tertulis ataupun film lain dari rekaman yang tidak dipersiapkan karena adanya permintaan seseorang (Moleong 2006). Dokumentasi dalam penelitian 
mengenai penggunaan sikep penglaris oleh masayarakat dusun Tumpangrejo berupa foto informan saat melakukan kegiatan, wawancara dengan informan, proses pembuatan sikep penglaris, serta foto lain yang dapat memperkuat hasil dalam penelitian.

Analisis data yang terkumpul dilakukan dengan identifikasi hasil observasi lapangan dengan tidak menegasikan data hasil wawancara dengan para informan untuk dilakukan abstraksi data yang terkumpul. Data kemudian dikategorisasikan berdasar kesesuaian menurut jenis dan relevansinya dengan fokus penelitian. Validasi data dilakukan dengan model triangulasi data yang terdiri dari beberapa prosedur, yaitu reduksi data, sajian data, dan penarikan kesimpulan. Reduksi data dilakukan dengan kategorisasi data berdasar tema yang relevan yang kemudian disajikan sistematis berdasar pada fokus penelitian. Data yang telah tersaji dilakukan proses interpretasi data dan kemudian ditarik kesimpulan pasca dilakukan cek-ricek terhadap sumber lain. Upaya triangulasi ini dilakukan sebagai upaya terhadap akurasi penelitian dengan penerapan tahapan prosedur tertentu (Bungin, 2012).

\section{Hasil dan Pembahasan}

\subsection{Latar Sosial Masyarakat}

Dusun Tumpangrejo merupakan salah satu dusun di Desa Kebobang, Kecamatan Wonosari, Kabupaten Malang. Desa ini terletak di sebelah Selatan lereng Gunung Kawi. Sebelum dilakukan pemekaran desa, Desa Kebobang memiliki satu wilayah yang terkenal sebagai tempat wisata spiritual, yaitu Pesarean Gunung Kawi yang kini termasuk dalam wilayah Desa Wonosari. Pemekaran wilayah Desa Kebobang menjadi Desa Wonosari disebabkan Desa Wonosari menjadi tempat tujuan wisata spiritual yang semakin ramai dikunjungi wisatawan baik domestik maupun manca negara. Pada tahun 2002, Bupati Malang mencanangkan dan menetapkan Desa Wonosari sebagai "Desa Wisata Ritual Gunung Kawi". Desa wisata ini ramai dikunjungi utamanya di area pesarean Gunung Kawi. Hari-hari tertentu dalam pasaran Jawa, seperti Jumat Legi, Senin Pahing, dan bulan Sura (Muharam) merupakan peak season desa wisata.

Desa Kebobang yang menjadi lokus penelitian ini mayoritas memeluk agama Islam dengan jumlah 8745 jiwa dan lebih dari $35 \%$ bekerja pada sektor informal atau berjumlah 3416 jiwa. Banyaknya warga yang menjadi pedagang karena Desa Kebobang memiliki pasar tradisional yang representatif dan sering dikunjungi oleh warga maupun wisatawan untuk melakukan transaksi jual beli di Pasar Kebobang. Pasar ini terletak di Dusun Tumpangrejo sebagai bagian dari Desa Kebobang sehingga tak mengherankan warga Dusun Tumpangrejo didominasi oleh pedagang sekaligus memiliki jumlah penduduk tertinggi di antara dusun lainnya yang jumlahnya 2785 jiwa. Selain berdagang di pasar, warga Dusun Tumpangrejo juga banyak yang membuka peluang usaha di rumah.

Secara geografis, letak Dusun Tumpangrejo yang berdekatan secara langsung dengan Gunung Kawi membuat masyarakat dusun ini kental dengan mitos, tradisi kejawen dengan segala ritualnya yang dikenal dan biasa disebut dengan istilah Islam Aboge. Tradisi dengan ragam ritualnya terus dilakukan dan diinternalisasikan oleh masyarakat. Internalisasi yang sedemikian massif yang dilakukan secara turun-temurun oleh nenek moyang menjadikan masyarakat enggan untuk meninggalkan ajaran yang telah dititahkan kepada penerusnya karena khawatir kualat, durhaka, dan kata buruk lainnya terpatri di benak masyarakat (Suberi, 2014).

Dalam melakukan kegiatan pemenuhan kebutuhan, sebagian masyarakat Dusun Tumpangrejo yang tergabung dalam komunitas Islam Aboge tidak dapat terlepas dari tradisi-tradisi yang telah diyakini dapat membantu memperlancar usaha. Salah satu tradisi yang dilakukan masyarakat agar mendapat kelancaran dalam berdagang yaitu tradisi ngitung dino yang wajib ada sebelum melakukan hajatan baik bersifat pribadi 
maupun kelompok. Masih banyak tradisi lainnya yang terus dijaga masyarakat melalui proses internalisasi dan konstruksi leluhur dengan ragam tujuan dan rasionalitasnya (Nugraha, 2010).

\subsection{Proses Pembuatan Sikep Penglaris}

Bagi masyarakat Aboge dalam menjalankan sebuah tradisi, antara tradisi satu dengan lainnya merupakan hal yang saling berkaitan. Begitu pula dengan tradisi pembuatan sikep penglaris. Dalam proses pembuatan sikep penglaris di dalamnya juga terdapat tradisi lainnya yang biasa dilakukan oleh masyarakat, seperti ngitung dino, poso weton, selametan, dan lain-lain. Ditambah lagi dalam pembuatan sikep penglaris antara informan satu dengan yang lainnya berpotensi memiliki tahap atau proses yang berbeda. Hal ini dikarenakan media yang digunakan sebagai sikep penglaris tergantung pada keyakinan benda yang dimiliki pembuat sikep. Ada yang memakai media berupa tulisan Arab, aksara Jawa, bunga, doa dalam bahasa Jawa, minyak wangi, dan benda lainnya. Perbedaan dalam pembuatan sikep penglaris dikarenakan perbedaan guru yang mengajarkan ilmu selama proses ngaji (belajar) ilmu Jawa. Sejalan yang disampaikan pembuat sikep yaitu Mbah Cipto seperti yang dituturkan berikut.

"Bedo-bedo tergantung wong sing nggawekno karo sing ngajarno, saben uwong duwe ilmu lan kepercayaan ning benda sing bedo, biasane ono sing nggawe benang, kembang, tulisan Jowo, tulisan Arab lan liya-liyane. Lek ning Jowo iku ono jenenge nini among kaki among sing njogo rogone awak dewe njaluke opo. Bedo deso wes bedo coro tergantung nini among kaki amonge njaluke opo supoyo slamet teko cilok".

Artinya: Beda-beda tergantung orang yang membuatkan dan yang mengajarkan, setiap orang memiliki ilmu dan kepercayaan kepada benda yang berbeda biasanya ada yang memakai benang, bunga, tulisan Jawa, tulisan Arab dan lain-lain Kalau di Jawa itu ada yang namanya nini among kaki among yang menjaga raga diri kita meminta apa. Berbeda desa sudah berbeda cara tergantung nini among kaki amongnya meminta apa agar selamat dari celaka.

Dari temuan penelitian terdapat dua aras besar bagaimana tradisi sikep penglaris ini dijalankan. Aras pertama yaitu pada proses pembuatan sikep penglaris yang dilakukan oleh orang pertama menggunakan dua media, yaitu dungo (doa) dan minyak wangi. Dalam membuat sikep penglaris yang pertama, melakukan tradisi ngitung dino. Ngitung dino atau mencari hari baik ketika hendak mengawali bekerja penting dilakukan sebelum membuat sikep penglaris karena saling berhubungan. Jika membuat sikep penglaris tanpa menghitung hari baik sebelumnya akan dianggap sia-sia. Kedua, calon pengguna sikep penglaris wajib untuk ngapalne dungo (menghafalkan doa) sebagai media pertama. Doa yang dihafalkan yaitu doa dalam bahasa Jawa yang bertujuan meminta rezeki, kelancaran dalam bekerja, dan perlindungan. Tahapan ini sejalan dengan yang disampaikan pembuat sedulur sikep lainnya, yaitu mbah Sutik sebagaimana yang disampaikan

"Kerono urip ning tanah jowo wong Aboge percoyo lek arep ngawiti sembarang ngitung dinane ora pas engko bakal nggowo balak"

Artinya: "Karena hidup di tanah jawa, orang Aboge percaya kalau setiap hendak memulai sesuatu kalau tidak pas nanti akan membawa celaka".

Dalam penggunaan sikep penglaris dengan media doa, doa dibaca sebelum berangkat bekerja tanpa melihat tulisan. Jika calon pengguna sikep penglaris belum menghafalkan doa maka tidak dapat melanjutkan pada tahap selanjutnya. Ketiga, calon pengguna sikep penglaris harus melakukan poso weton (puasa weton) dan 
metri (syukuran). Puasa weton dilakukan sebagai wujud tirakat dalam membuat sikep penglaris dan metri dilakukan sebagai bentuk ucapan rasa syukur karena telah mampu melaksanakan tirakat. Persyaratan dalam melakukan metri yaitu wajib menyediakan ayam kampung berwarna putih dan memiliki jalu yang nantinya akan digunakan sebagai lauk tumpeng. Ayam kampung berwarna putih merupakan simbol bahwa sikep penglaris bersifat suci (lihat gambar 1).

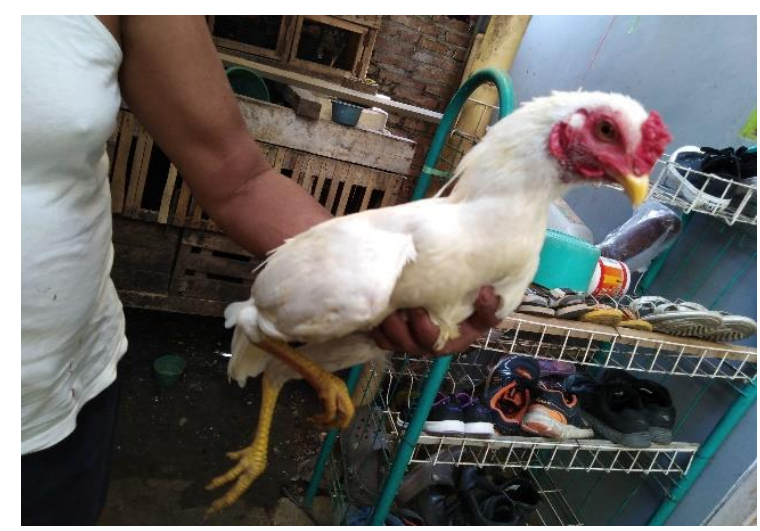

Gambar 1. Simbolik Sikep Penglaris yang berarti suci

Selain calon pengguna, pada tahap ini pembuat sikep penglaris juga melakukan tirakat untuk minyak wangi yang digunakan sebagai media sikep penglaris. Selanjutnya dengan berpuasa dan membaca doa khusus. Minyak wangi yang sudah ditirakati oleh pembuat sikep penglaris digunakan pada saat selesai membaca doa sebelum berangkat bekerja bertujuan sebagai simbol untuk meminta perlindungan dan kelancaran dalam bekerja. Setelah melalui tahap pembuatan dan agar sikep tersebut dapat memiliki manfaat, satu hal yang harus dilakukan oleh pengguna sikep penglaris yaitu tetap melakukan tirakat dengan puasa weton setiap bulan atau setiap tahun.

Selanjutnya aras kedua dalam proses pembuatan sikep penglaris yang dilakukan oleh orang kedua menggunakan media aksara Jawa yang dalam penulisannya dimulai dari belakang. Tahap pertama yang dilakukan dalam pembuatan sikep penglaris yaitu dengan ngaweruhne weton. Dalam tahap ini, weton yang dipakai untuk membuat sikep penglaris bagi orang yang sudah menikah adalah memakai weton istri. Hal ini dikarenakan dalam pengetahuan masyarakat Jawa istri diibaratkan sebagai daringan (wadah beras) yang harus dijaga. Kedua, pembuat sikep penglaris akan memberikan secarik kertas berisi aksara jawa dan satu bungkus kembang telon (bunga tiga jenis) yang isinya adalah bunga kenanga, kantil putih, dan kantil kuning. Selanjutnya calon pengguna sikep penglaris harus melakukan tirakat dengan membaca aksara Jawa yang telah diberikan setiap jam 12 malam dan dilanjutkan dengan mandi, kemudian menaburkan bunga yang diberikan di halaman rumah. Hal ini dilakukan selama 7 hari berturut-turut. Selama calon pengguna sikep penglaris melakukan tirakat, hal yang sama juga dilakukan oleh pembuat sikep penglaris dengan membaca doa khusus. Pada pembuatan sikep penglaris oleh orang kedua, pengguna sikep wajib untuk melakukan tirakat lanjutan untuk memperbarui sikep penglaris caranya adalah dengan melakukan puasa weton setiap bulan dan membuat jenang abang (bubur merah). Tirakat untuk memperbarui weton ini dilakukan karena sikep penglaris diibaratkan sebagai pagar hidup (tumbuhan) yang harus dipupuk agar tetap dapat memberikan manfaat bagi penggunanya.

Dari ketiga proses pembuatan sikep penglaris di atas dapat dilihat bahwa ada satu hal yang menjadi kunci dalam proses pembuatan sikep penglaris meskipun berbeda dalam tahapan dan media yang digunakan, yaitu tirakat yang dilakukan oleh pengguna sikep penglaris. Mereka meyakini bahwa upaya tirakat yang dilakukan secara pribadi oleh pengguna seperti berpuasa weton setiap bulan dapat membawa pengaruh pada manfaat dari sikep penglaris. Berikut tahapan dalam sikep penglaris dengan dua model (lihat tabel 1).

Selain itu, dalam proses pembuatan sikep penglaris terdapat doa kepada Allah SWT dengan hajat agar dagangannya dapat laris sehingga disebut penglaris. Analisis doa menunjukan bahwa doa tersebut 
dinyatakan secara Islam diawali dengan salam, salawat kepada Nabi Muhammad SAW, dan diakhiri dengan kalimat la ilaha illallah. Doa diberikan oleh seseorang yang dipercaya menguasai pengetahuan dan keahlian khusus atau biasa disebut wong pinter. Manfaat dari doa yang diberikan oleh orang tersebut kepada masyarakat secara empiris terbukti makbul. Orang tersebut juga menambah konsentrasi agar berdampak secara psikologis. Hal ini dapat dilihat dari inti sari doa yang ditujukan kepada Allah SWT dan Nabi Muhammad SAW, serta makna simbolis dari isi sesajen yang wajib dipenuhi yaitu ayam kampung putih menandakan bahwa sikep penglaris bersifat suci. Berikut doa yang selalu dipanjatkan oleh pengguna sikep penglaris.

"Salamualaikumsalam, sedulurku kakang kawah adi ari-ari, sedulurku kaki among nini among, sedulurku kiblat papat, limo pancer, enem nyowo, pitu sukmo. Sedulurku ingkang tumetes bumi tumetes tuyo, kakang kalas kakang kowo siro ngumpulo, yen wis ngumpul masuko menyang rogo sejati sebo o Yang Maha Suci. Ayo nyambut gawe njaluk rejeki, njaluk selamet nduyo kelawan akhirat, Yang Maha Suci ideni Allah kang nampani, Muhammad kang nuruni. Mari ngono moco (Laillahaillallah ya Muhammad 3x) karo megeng nafas"
Artinya: "Salamualaikumsalam, saudaraku air ketuban, ari-ari (plasenta), saudaraku kaki among nini among, saudaraku kiblat empat, lima tengah, enam nyawa, tujuh sukma. Saudaraku yang menetes bumi, menetes air, kakang kalas kakang kowo ayo berkumpul, kalau sudah berkumpul masuklah kedalam raga sejati menghadap Yang Maha Suci. Ayo bekerja untuk meminta rezeki, meminta selamat dunia dan akhirat. Yang Maha Suci Allah yang menerima, Muhammad yang memberikan. Setelah itu membaca (Lailahaillallah ya Muhammad 3x) dengan menahan nafas",

Proses doa dilakukan dengan ketentuan sangat ketat mulai isi doa, pembacaan doa, penjelasan inti doa, waktu berdoa dan tempat, serta tata cara meletakkan sesuatu yang sakral setelah berdoa. Penglaris yang selama ini diberi stigma negatif oleh masyarakat ternyata merupakan doa secara Islam untuk memohon kepada Allah SWT agar dagangannya laris. Doa agar khusyuk yang dipahami oleh masyarakat dilakukan dengan ajaran Islam, yaitu salam, salawat, dan kalimat la ilaha illallah serta tujuan hajatnya dinyatakan dalam bahasa Jawa. Dalam hal ini menunjukan bahwa terdapat proses Islamisasi pada masyarakat Dusun Tumpangrejo dengan media pemenuhan kebutuhan masyarakat (Woodward, 2004).

Tabel 1 Alir Proses Sikep Penglaris dengan Tipologinya

\begin{tabular}{|c|c|c|c|}
\hline & Tipe Sikep Penglaris 1 & Tipe Sikep Penglaris 2 & $\begin{array}{c}\text { Hal yang Dilakukan } \\
\text { Bersama }\end{array}$ \\
\hline $\begin{array}{c}\text { Pembuat Sikep } \\
\text { Penglaris }\end{array}$ & $\begin{array}{ll}\text { - } & \text { Memberikan dungo } \\
\text { aksara Jawa } \\
\text { - } \\
\text { Memberikan } \\
\text { kembang telon } \\
\text { - Tirakat membaca } \\
\text { doa khusus }\end{array}$ & 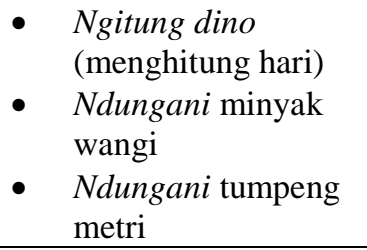 & $\begin{array}{l}\text { Tirakat poso weton dan } \\
\text { metri dengan jenang } \\
\text { abang (bubur merah) }\end{array}$ \\
\hline $\begin{array}{c}\text { Pengguna Sikep } \\
\text { Penglaris }\end{array}$ & $\begin{array}{ll}\text { - } & \begin{array}{l}\text { Ngaweruhne weton } \\
\text { (memberitahukan }\end{array} \\
\text { hari kelahiran) }\end{array}$ & $\begin{array}{ll}\text { - } & \text { Ngapalne dungo } \\
\text { (menghafal doa) }\end{array}$ & $\begin{array}{l}\text { Poso weton (berpuasa) } \\
\text { setiap bulan atau setiap } \\
\text { tahun }\end{array}$ \\
\hline
\end{tabular}


dan keramas,

menabur kembang

telon di depan

rumah)

\subsection{Sikep Penglaris dan Rasionalitasnya}

Masyarakat Dusun Tumpangrejo yang yang merupakan penganut kepercayaan Islam Aboge (Alif Rebo Wage) dikenal sebagai Islam Kejawen. Hal ini dikarenakan masyarakat masih memegang teguh pemahaman yang diberikan oleh leluhur mengenai tradisi dan tidak berani untuk meninggalkan tradisi yang seolah telah diwariskan (Yaqin, 2018). Keberadaan masyarakat Aboge di Dusun Tumpangrejo terlihat mencolok utamanya ketika melakukan hari besar umat Islam, seperti Idul Adha dan Idul Fitri. Pada saat Idul Fitri misalnya, salah satu perbedaan dengan masyarakat lainnya adalah masyarakat Aboge percaya dengan adanya sukmo (sukma) leluhur yang memberikan warisan tradisi yang masih berada di sekitar. Masyarakat Aboge percaya bahwa sebagai keturunannya hendaknya masyarakat senantiasa melaksanakan tradisi-tradisi yang sudah diajarkan secara turun-temurun dan tidak boleh meninggalkannya. Paradigma metafisik Comtenian nampak dalam masyarakat Aboge (Dozan \& Rohimi, 2019). Menjadi keturunan Aboge dan bertempat tinggal pada lingkungan yang taat menjalankan tradisi Aboge warisan leluhur membuat sebagian masyarakat tidak memiliki keberanian untuk meninggalkan tradisi yang sudah dilakukan secara turuntemurun, meskipun masyarakat pada umumnya sudah hidup pada kehidupan sosial yang modern.

Tradisi yang masih dijalankan oleh masyarakat Aboge Dusun Tumpangrejo adalah menggunakan sikep penglaris hingga saat ini. Berdasarkan penuturan dari sesepuh Aboge, ia menjelaskan bahwa sikep penglaris adalah salah satu dari beberapa jenis sikep yang diyakini dan terus ditradisikan. Penggunaan sikep dilakukan oleh masyarakat Aboge pada umumnya bertujuan untuk melindungi segala sesuatu yang disesuaikan dengan kepentingan penggunannya. Sikep memiliki beberapa jenis, yakni sikep omah (sikep rumah) untuk melindungi penghuni rumah, sikep keslametan (sikep keselamatan) untuk melindungi diri dari mara bahaya dan menghadirkan keselamatan, dan sikep penglaris (sikep pelaris) sebagai upaya untuk mencari keuntungan atau penglarisan dalam usaha perdagangannya.

Bagi masyarakat Aboge Dusun Tumpangrejo, tradisi menggunakan sikep salah satunya sikep penglaris bukanlah sesuatu yang dapat merugikan orang lain, tetapi anggapan masyarakat umum (bukan Aboge) mengenai sikep penglaris yang dianggap keliru oleh masyarakat Aboge menyamakannya dengan pesugihan. Menurut penuturan sesepuh Dusun Tumpangrejo antara sikep penglaris dan pesugihan merupakan dua hal yang sangat berbeda. Hal ini didasarkan pada niat dan proses pembuatan dari sikep tersebut yang menganjurkan pemakainya untuk menjaga perilaku yang baik melalui tirakat sedangkan sangat berbanding terbalik dengan sifat dari pesugihan. Selain itu sikep dianggap sebagai hal yang suci sehingga tidak boleh digunakan untuk mencelakai atau merugikan orang lain. Jika sikep digunakan untuk mencelakai atau merugikan orang lain dipercaya akan membawa celaka bagi penggunanya. Bagi pembuat sikep, jika membuatkan sikep dengan tujuan yang buruk hal tersebut dipercaya akan menutup pintu rezekinya sendiri. 
Menurut penuturan sesepuh yaitu Mbah Cipto, sikep penglaris banyak digunakan oleh masyarakat Aboge Dusun Tumpangrejo khususnya bagi yang bekerja sebagai pedagang karena fungsi dan kegunaannya. Pemakaian sikep penglaris sudah dianggap sebagai tradisi turun-temurun yang dilakukan nenek moyangnya sebelum memulai berdagang. Warisan leluhur ini dipercaya dapat melindungi toko atau warung dari gangguan magis yang sengaja dilakukan oleh seseorang melalui perantara orang pintar lainnya karena motif-motif tertentu, seperti kalah saing atau agar usahanya bisa mengalahkan koleganya, atau tempat tersebut memang dipercaya tidak memiliki peruntungan bisnis yang bagus.

Dalam menggunakan sikep penglaris setiap orang memiliki alasan dan rasionalitas masing-masing. Beberapa latar belakang yang mendasari tetap digunakannya sikep penglaris hingga saat ini, yaitu pertama, karena mendapat nasihat dari orang tua yang sebelumnya juga merupakan seorang pedagang. Nasihat ini merupakan nasihat yang tak boleh dibantah. Salah satu prosesnya yaitu sebelum memulai berdagang orang tua menyarankan kepada anak untuk membuat sikep penglaris dengan bantuan sesepuh atau orang pintar di Dusun Tumpangrejo. Hal ini dikarenakan memakai sikep penglaris dianggap sebagai ritual atau tradisi yang harus dilakukan sebelum memulai berdagang. Kedua, agar dagangan laris. Selain menjalankan tradisi yang diajarkan oleh orang tua, dalam menggunakan sikep penglaris merupakan salah satu wujud upaya yang dilakukan agar dagangan laris dan hal tersebut oleh salah satu informan dibuktikan dengan hingga saat ini usaha yang dirintis telah berjalan lancar selama 30 tahun. Ketiga, agar mendapat perlindungan dari gangguan magis. Gangguan magis dapat menyebabkan kerugian dalam berdagang yang bisa terjadi sewaktu-waktu. Menurut salah satu informan, sebagian orang Jawa terlebih masyarakat Aboge ketika memiliki permasalahan personal pada konteks persaingan perdagangan dapat melakukan segala cara agar dapat menjatuhkan lawan bisnis melalui perantara dukun atau orang pintar.

Secara teoretis, menurut Webber (Bagus, 2012), seseorang dalam bertindak tidak hanya sekedar melaksanakan, tetapi juga menempatkan diri dalam lingkungan berpikir dan berperilaku orang lain. Rasionalitas setiap individu dalam penggunaan sikep penglaris berbeda yang seringkali dipengaruhi faktor lingkungan dan bagaimana perilaku orang lain memberikan pengaruh bagi individu. Salah satu rasionalitas versi Webber dalam penggunaan sikep penglaris adalah rasional tindakan tradisional. Tindakan penggunaan sikep ditentukan oleh kebiasaan-kebiasaan yang sudah mengakar kuat secara turuntemurun dan tetap dilestarikan dari generasi ke generasi. Bagi masyarakat Aboge, penggunaan sikep merupakan salah satu tradisi warisan leluhur. Melestarikan apa yang telah dilakukan oleh leluhur bagi masyarakat Aboge adalah suatu hal yang penting karena di dalamnya terdapat nilai historis yang dapat diambil sebagai nilai moral untuk diterapkan oleh generasi selanjutnya.

Dalam masyarakat Jawa, upaya menjaga tradisi dilakukan dengan tetap memegang teguh warisan leluhur. Upaya yang dilakukan oleh masyarakat Aboge Dusun Tumpangrejo untuk melestarikan tradisi yaitu dengan cara tetap melakukan tradisi kejawen seperti memakai sikep penglaris. Tradisi ini sudah dilakukan secara turun-temurun oleh masyarakat Aboge Dusun Tumpangrejo khususnya yang bekerja sebagai pedagang sebagai upaya untuk melindungi dan memberikan kelancaran dalam bekerja. 


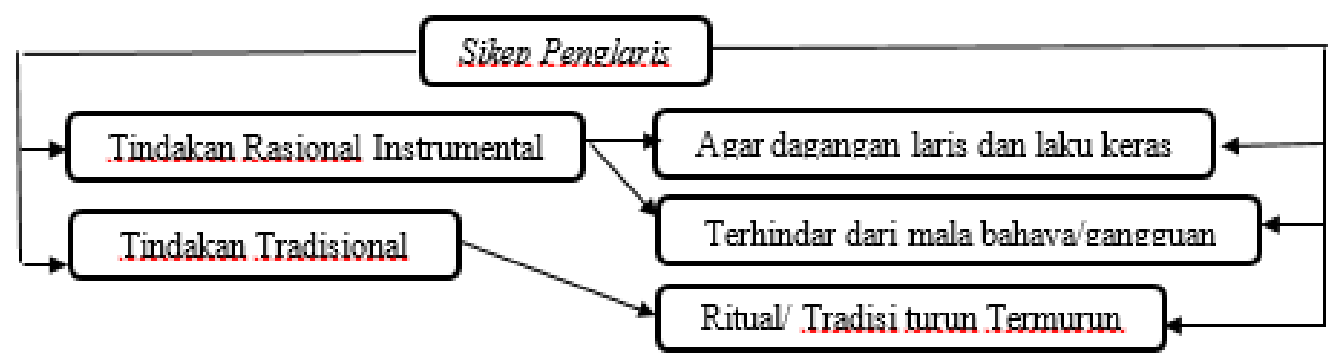

Gambar 2 Visualisasi Temuan Penelitian

Kedua, yaitu tindakan rasionalitas instrumental. Menurut teori ini tindakan ditujukan pada pencapaian tujuan yang secara rasional diperhitungkan dan diupayakan sendiri oleh aktor yang bersangkutan. Secara rasional informan yang bekerja sebagai pedagang berharap dagangan yang dijual dapat laku keras (laris) dan nantinya para pedagang akan mendapat keuntungan yang dapat digunakan untuk memenuhi kebutuhan sandang pangan keluarga. Sikep penglaris menjadi salah satu jalannya. Upaya yang dilakukan oleh masyarakat Aboge Dusun Tumpangrejo yang bekerja sebagai pedagang untuk mencapai tujuan tersebut selain melalui usaha fisik dengan membangun bedak (toko) di lokasi yang strategis, mereka juga melakukan usaha spiritual dengan melakukan tradisi menggunakan sikep penglaris yang dipercaya dapat melariskan dagangan. Dalam satu tindakan yang dilakukan yang dilakukan oleh setiap individu maupun kelompok dapat memiliki alasan yang berbeda-beda. Dalam konteks ini setiap informan juga memiliki perbedaan dalam latar belakang yang mendasari penggunaan sikep penglaris (gambar 2).

\section{Kesimpulan}

Dalam melakukan kegiatan pemenuhan kebutuhan, sebagian masyarakat Islam Aboge tidak dapat terlepas dari tradisi yang telah diyakini dapat membantu memperlancar usaha melalui penggunaan sikep penglaris. Alasan yang melatarbelakangi penggunaan sikep penglaris yaitu karena nasihat dari orang tua yang turun temurun yang dianggap sudah seperti bagian dari tradisi sebelum memulai berdagang. Alasan lainnya bertujuan agar dagangan laris sekaligus mendapat perlindungan dari gangguan magis. Untuk mendapatkan sikep penglaris terdapat tata cara dan proses yang harus ditempuh oleh calon pengguna sikep. Baik pengguna maupun pembuat sikep memiliki tahapan berbeda yang harus dilakukan. Bagi pembuat sikep mereka di antaranya harus melakukan tradisi yang disebut ngitung dino dan ndungani, sedangkan bagi pengguna diharuskan untuk menghafalkan doa yang telah diberikan sekaligus melakukan ritual berpuasa sesuai dengan weton (waktu).

Proses pembuatan sikep penglaris berpotensi memiliki perbedaan antara satu dan lainnya. Hal ini dikarenakan setiap pembuat sikep memiliki kepercayaan yang berbeda terhadap benda media sikep penglaris dan perbedaan guru dalam ngaji ngilmu jowo (belajar ilmu Jawa). Kunci dalam proses pembuatan sikep penglaris meskipun berbeda dalam tahapan dan media yang digunakan yaitu tirakat yang dilakukan oleh pengguna sikep penglaris. Penglaris yang selama ini diberi stigma negatif oleh masyarakat ternyata merupakan doa secara Islam untuk memohon kepada Allah agar 
dagangannya laris. Bertahannya sikep penglaris hingga saat ini tidak terlepas dari proses konstruksi yang terus berputar secara dialektis dalam kehidupan sosial masyarakat Dusun Tumpangrejo dengan rasionalitas tradisional dan instrumental masing-masing individu.

\section{Daftar Pustaka}

Akhmad, P., \& Psi, S. (2017). Membongkar Kesesatan perilaku syirik masyarakat Indonesia. Yogyakarta: Quranic Media Pustaka

Arroisi, J. (2015). Aliran Kepercayaan \& Kebatinan: Membaca Tradisi dan Budaya Sinkretis Masyarakat Jawa. $A l$ Hikmah: Jurnal Studi Agama-Agama, 1 (1), 1-28. Retrieved from http://journal.um-surabaya.ac.id /index.php/Ah/article/view/946/pdf

Bagus, W. I. (2012). Teori-Teori Sosial dalam Tiga Paradigma. Jakarta: Kencana

Bungin, B. (2012). Analisa Data Penelitian Kualitatif. Jakarta: Rajawali Press

Dozan, W., \& Rohimi, R. (2019). Logika Penemuan Ilmiah Teori (Possitivisme Logis) August Comte. Kontemplasi: Jurnal Ilmu-Ilmu Ushuluddin, 7(2), 190-211. https://doi.org/10.21274/ kontem.2019.7.2.190-211

Endraswara, S. (2006). Metodologi Penelitian Kebudayaan. Gajah Mada Universitas Press

Giri, W. (2010). Sajen dan Ritual Orang Jawa. Yogykarta: Penerbit Narasi

Hasyim, R. N. B. (2018). Penglaris dalam perspektif Kyai Ilmu Hikmah [PhD Thesis]. UIN Sunan Ampel Surabaya

Herniti, E. (2014). Kepercayaan Masyarakat Jawa Terhadap Santet, Wangsit, dan Roh Menurut Perspektif Edwards Evans-Pritchard. THAQAFIYYAT: Jurnal Bahasa, Peradaban Dan Informasi Islam, 13(2). Retrieved from http://ejournal.uin-suka.ac.id /adab/thaqafiyyat/article/view/77

Idrus, M. (2007). Makna agama dan budaya bagi orang jawa. Unisia, 30(66). Retrieved from https://journal. uii.ac.id/Unisia/article/view/2683/2462

Indrasuari, A. F. (2012). Kepercayaan Pedagang Terhadap Wong Pinter Dalam Menunjang Usaha Dagang Di Pasar Bintoro Demak. Solidarity: Journal of Education, Society and Culture, 1 (1). Retrieved from https://journal.unnes.ac.id/sju/index.ph $\mathrm{p} /$ solidarity/article/view/217

Jaya, P. H. I. (2012). Dinamika pola pikir orang Jawa di tengah arus modernisasi. Humaniora, 24(2), 133-140. https://doi.org/10.22146/jh.1056

Jones, P. (2003). Pengantar Teori-Teori Sosial: Dari Teori Fungsionalisme Hingga Post Modernisme (Saifusdin, Trans.). Jakarta: Pustaka Obor

Khoiri, A. (2019). Kepercayaan Terhadap Benda-Benda Mistis Masyarakat (Studi Terhadap Rajah Jimat Desa Bulusari Kedungwaru Tulungagung Kajian Fenomologi Edmund Husserl) [PhD Thesis]. IAIN Tulungagung.

Koentjaraningrat. (2009). Pengantar Ilmu Antropologi. Yogyakarta: Rineka Cipta

Moleong, L. J. (2006). Metode Penelitian Kualitatif. Bandung: PT. Remaja Rosda Karya

Neuman, W. L. (2014). Social Reseacrh Methods: Qualitative and Quantitative Approaches (7th ed.). Person Education Limited.

Nourse, J. W. (2013). The meaning of dukun and allure of Sufi healers: How Persian cosmopolitans transformed MalayIndonesian history. Journal of Southeast Asian Studies, 44(3), 400-422. Retrieved from http://www.jstor.org/stable/43863213 
Nugraha, H. M. C. (2010). Kepercayaan Pedagang Terhadap Penglaris (Studi pada Warung Kopi di Desa Bolorejo, Kecamatan Kauman, Kabupaten Tulungagung) [PhD Thesis]. University of Muhammadiyah Malang

Nurdin, A. (2012). Komunikasi Magis Dukun (Studi Fenomenologi Tentang Kompetensi Komunikasi Dukun). Jurnal ASPIKOM, 1(5), 383-402. doi:http://dx.doi.org/10.24329/aspikom .v1i5.43

Prawiro, A. M. B. (2013). Islam Aboge: Islam and Cultural Java Dialogue (A Study of Islam Aboge Communities in Ujungmanik, Cilacap, Central Java, Indonesia). International Journal of Nusantara Islam, 1(2), 102-117. doi: https:// doi.org/ 10.15575/ijni.v1i2.29

Ritzer, G., \& Goodman, D. J. (2016). Teori Sosiologi: Dari Teori Klasik Sampai Perkembangan Mutakhir Teori Sosial Modern (11th ed.). Yogyakarta: Kreasi Wacana

Sakirman, S. (2016). Islam Aboge Dalam Tradisi Jawa Alastua. IBDA: Jurnal Kajian Islam Dan Budaya, 14(2), 172187. doi: http://dx.doi.org/10.24090/IBDA.V14 10.24090/IBDA.V14I2.702

Sartini. (2014). Wong Pinter di antara Para Penyembuh Tradisional Jawa. Balai Kajian Sejarah Dan Nilai Tradisional Yogyakarta, 15 (4). http://repository.ugm.ac.id/96985/1/Pat ra\%20Widya\%20Des\%202014\%20Vol \%2015\%20No.\%204\%20Wong\%20Pi nter\%20in\%20Javanese\%20Discourse. pdf

Simuh. (2003). Islam dan Pergumulan Budaya Jawa. Jakarta: Teraju.

Suberi, M. (2014). Persepsi Pedagang Di Bojonegoro Terhadap Kepercayaan Adanya Klenik Sebagai Penglaris Dagangannya. Jurnal Manajemen Dan Penelitian Akuntansi (JUMPA), 7(2),
89-97. Retrieved from http://ejournal.stiekia.ac.id/index.php/J UMPA/article/view/27/22

Turner, B. S. (2012). Teori Sosial dari Klasik sampai postmordern. Yogyakarta: Pustaka Pelajar.

Woodward, R. M. (2004). Islam Jawa: Kesalehan Normatif Versus Kebatinan. Yogyakarta: LKiS.

Yaqin, H. (2018). Konstruksi Kearifan Lokal Islam Aboge di Probolinggo. Humanistika: Jurnal Keislaman, 4(1), 17-29.

doi: https://doi.org/10.36835/humanistika.v $4 \mathrm{i} 1.28$

Zulfiqar, E. (2016). Praktik Perdukunan Dalam Pentas Politik Lokal. Jurnal Ilmiah Muqoddimah: Jurnal Ilmu Sosial, Politik Dan Humaniora, 1(1). doi:http://dx.doi.org/10.31604/jim.v1i1 $.2016 . \% 25 p$ 